\title{
Occurrence of thorite and radioactive zircon in syenite pegmatite, North of Ashwaraopet, Khammam district, Andhra Pradesh, India
}

\author{
K SURYA PRAKASH RAO, R S N SASTRY and GAUTAM ROY \\ Applied Geochemistry (R \& T), Science College, Osmania University, Hyderabad 500007, \\ India. \\ MS received 31 May 1988; revised 3 February 1989

\begin{abstract}
This paper reports the occurrence of thorite and confirms the earlier find of radioactive zircon by Subbarao, Murali and others from syenite pegmatite in the Vinayakapuram-Kunavaram alkaline belt in the Khammam district of Andhra Pradesh, India. Thorite has also been found as residual concentrations in soil overlying the pegmatite.
\end{abstract}

Keywords. Thorite; zircon; syenite pegmatite; gamma-ray survey

\section{Introduction}

The belt of alkaline rocks between Vinayakapuram and Kunavaram was selected for a $\gamma$-ray spectrometric survey, which led to the identification of thorite and radioactive zircon from a syenite pegmatite south of the village of Nandipadu (figure 1). Extensive work on this belt has been reported earlier (Mahadevan and Satapati 1954; Krishnan 1968; Ramaswamy 1959; Subbarao 1964, 1967, 1971; (Rao and Murthy 1970, 1973; Sharma et al 1971; Murthy 1972; Murali et al 1983). The alkaline rocks are exposed in a chain of hills and ridges striking NE-SW. The belt is cut by Gondwana formations in the south, flanked by gneisses and alluvium in the east and amphibolites in the west. Paragneisses of the Eastern Ghats occur as conspicuous bands and patches in the syenites and amphibolites.

\section{Gamma-ray survey}

The area was surveyed with a Scintrex GIS-5 portable $\gamma$-ray spectrometer. The instrument was operated in the total count mode with an integration time of one second. The range of the normal background count in the area varied between 100 and $200 \mathrm{cps}$. The syenite pegmatite with its overlying residual concentration of thorite and zircon shows values between 300 and $1800 \mathrm{cps}$, with a point anomaly of 75,000 cps. Biotite-nepheline syenites north-west of Vinayakapuram show some smaller anomalies around $1200 \mathrm{cps}$.

\section{Mineralization}

The syenite pegmatite hosting thorite and radioactive zircons occurs in sheared quartz veins adjacent to the amphibole-nepheline syenites about $1 \mathrm{~km}$ south of the village 


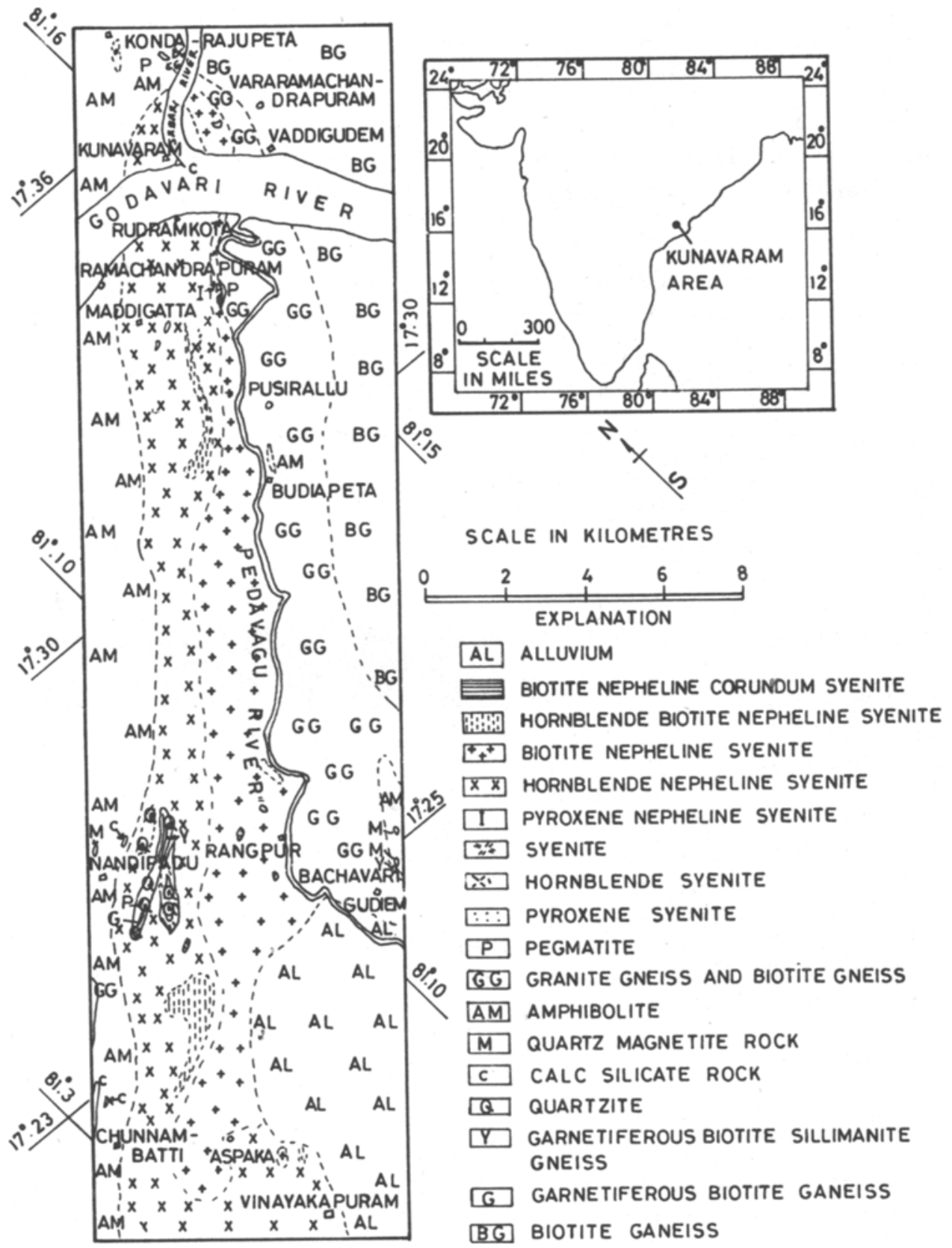

Figure 1. Location and geology of alkaline rocks of Vinayakapuram-Kunavaram belt (after Subbarao 1971).

Nandipadu. The pegmatite strikes NE-SW and cuts across the road to Nandipadu. It is highly weathered, and outcrops are few. The anomalous zone, as traced by $\gamma$-ray spectrometry can be followed over more than $500 \mathrm{~m}$ along strike, with a variable width of a few to more than $10 \mathrm{~m}$. Thorite was also observed as residual concentrations 
in soil above the pegmatite, where it forms a blanket of about $10 \mathrm{~cm}$ thickness below the top soil. The grain size ranges from 0.1 to $1.5 \mathrm{~cm}$, and the larger grains were, in fact, handpicked from the soil. Zircons show a similar dispersion in the soil and similar grain size. The weathered pegmatite was exposed in shallow pits below the residual concentration zone. The feldspars in the pegmatite are highly weathered and the zircons stand out prominently. Another generation of pegmatites in this locality is characterized by black tourmaline and shows low radioactivity.

\section{Mineralogical studies}

Thorite is black, and detrital grains can easily be separated by panning on account of its high specific gravity. It responds to a simple chemical test, as it dissolves in concentrated hydrochloric acid; the solution gelatinizes on concentration by heating. The grains of thorite are altered by weathering to a greater extent than the zircons. These are yellowish to reddish brown and can easily be mistaken for garnet. They display an unusually short prismatic habit and some grains resemble garnet not only in colour but in crystal habit as well. They can easily be recognized by their yellow fluorescence under ultraviolet light.

The minerals were confirmed by $\mathrm{X}$-ray powder diffraction studies using a Guinier camera (table 1). The diffraction lines were measured, and the $d$-values compared against a standard set compiled by JCPDS (1972).

Table 1. $d$-values for thorite and zircon from syenite pegmatite north of Ashwaraopet.

\begin{tabular}{llll}
\hline \multicolumn{3}{c}{ Thorite } & \multicolumn{2}{c}{ Zircon } \\
$d$ observed & $d$ standard & $d$ observed & $d$ standard \\
\hline $4.728(9)$ & $4.72(9)$ & & \\
$3.556(10)$ & $3.55(10)$ & $4.425(5)$ & $4.43(5)$ \\
& & $3.305(10)$ & $3.30(10)$ \\
$2.838(5)$ & $2.84(5)$ & & \\
- & $2.68(8)$ & & \\
$2.680(8)$ & $2.52(3)$ & $2.523(5)$ & $2.52(5)$ \\
$2.019(3)$ & & $2.339(3)$ & - \\
$1.886(2)$ & & $2.070(3)$ & $2.07(2)$ \\
$1.840(4)$ & $1.89(3)$ & $1.909(2)$ & $1.91(1)$ \\
& $1.83(7)$ & & \\
& & $1.749(2)$ & $1.75(1)$ \\
& & $1.710(5)$ & $1.71(4)$ \\
& & $1.649(2)$ & $1.65(1)$ \\
& & $1.382(2)$ & \\
& & $1.364(2)$ & $1.287(1)$ \\
& & $1.262(1)$ & \\
& & $1.189(1)$ & \\
& & &
\end{tabular}

Standard $d$-values from JCPDS (1972). Line intensities given in parantheses. 


\section{Discussion}

Thorium occurs in nature exclusively in the tetravalent state and forms rather insoluble minerals. Significant amounts of $\mathrm{Th}^{4+}$ can substitute in accessory minerals like zircon and sphene. Such substitution is possible because the radius of $\mathrm{Zr}^{4+}(0.80 \AA)$ is not too different from the radius of $\mathrm{Th}^{4+}(1.02 \AA)$. In the secondary environment thorium is mobile only as clastic and detrital grains in heavy fractions of soils and sediments, where the relatively resistant Th-minerals may become concentrated. Favourable conditions can lead to their concentrations in placer deposits, e.g. the Th-rich monazite sands of India.

Thorite was reported as a rare accessory in pegmatites from the Jos Plateau, Nigeria, in veins associated with carbonatites (Mountain Pass, California, and Powder Horn District, Colorado) and in other veins (Heinrich 1958). Its occurrence in syenite pegmatites was reported from Larvik and Langesundfjord area, Norway (Brфgger 1890; Siggerud 1956), and from nepheline syenites in eastern Siberia (Portnov 1967). Eight occurrences from USA associated with alkaline rocks and/or carbonatities have been listed by Staatz (1974). Occurrences of pegmatites with Th-minerals are numerous and markedly variable in their mineralogical associations. As pointed out by Heinrich (1958), pegmatites can represent the most common type of radioactive mineral deposit in hard rock terrains.

Radioactive zircons are found in a wide variety of felsic to intermediate igneous rocks. Associations with thorite in syenite pegmatites have been reported from the Langesundfjord area of Norway by Siggerud (1956), and also from the Haliburton-Bancroft area of southern Ontario by Satterly and Hewitt (1955). Reddish brown zircons in association with thorite, and containing numerous inclusions of thorite occur in the Jos Plateau, Nigeria. These zircons are also characterized by a garnet-like crystal habit (Schuiling 1989).

\section{Conclusions}

Thorite, in association with radioactive zircons, has been discovered in the syenite pegmatite from the Vinayakapuram-Kunavaram belt of alkaline rocks. The area contains a large number of pegmatites as reported earlier and a more extensive exploration programme is perhaps warranted. Detailed $\gamma$-ray surveys combined with geochemical investigations may lead to the identification of some productive zones of radioactive minerals. The chance of finding residual concentrations should not be overlooked in future studies as the larger grains of thorite could be handpicked from the soils during the present investigatiors.

\section{Acknowledgements}

The authors are grateful to Prof R D Schuiling, Principal Scientific Advisor for Applied Geochemistry (R \& T) from Utrecht University, Netherlands for a critical revision of the paper. They are also thankful to Prof. $T$ Navaneeth Rao for constant encouragement. 


\section{References}

Brögger W C 1890 Die Mineralien der Syenitpegmatitgäng der südnorwegischen Augit- und Nephelinsyenite; Z. Kryst. 16 pp. 663

Heinrich E Wm 1958 Mineralogy and geology of radioactive raw materials (New York: McGraw Hill)

JCPDS 1972 Inorganic index to the powder diffraction file (ed.) L G Berry (Pennsylvania: Joint Committee on Powder Diffraction Standards)

Krishnan M S 1968 Geology of Indian and Burma (Madras: Higginbothams)

Mahadevan C and Satapati N 1954 Nepheline syenites and their economic uses; Trans. Indian Ceramic Soc. 13 204-210

Murali A V, Parthasarathy R, Mahadevan T M and Shankar Das M 1983 Trace Element Characteristics, REE pattern and partition coefficients of Zircons from different geological environments - A case study on Indian Zircons; Geochim. et Cosmochim. Acta 47 2047-2052

Murthy I S N 1972 Studies on Alkaline rocks of Khammam district, Andhra Pradesh, India; Ph.D. thesis submitted to Osmania University (unpublished)

Portnov A M 1967 A new type of rare-metal mineralization genetically related to nepheline syenites; Geol. Rud. Mestorozhd. 9 74-75

Ramaswamy C 1959 Geology of parts of Bhadrachalam taluk, East Godavari District, Andhra Pradesh; Progress report Geol. Surv. India (unpublished)

Rao Y J and Murthy I S N 1970 The alkaline rock complex of Vinayakapuram-Kunavaram area, Khammam district, A.P.; J. Indian Geosci. Assoc. 12 pp. 89

Rao Y J and Murthy I S N 1973 On the occurrence of Carbonatites in the Vinayakapuram Nepheline syenite band, Khammam district, Andhra Pradesh; J. Geol. Soc. India 14 431-433

Satterly $J$ and Hewitt F 1955 Some radioactive mineral occurrences in the Bancroft area, Ontario; Ontario Dept. Mines Geology Cir. 2

Schuiling R D 1989 Garnet-like zircons from India and Nigeria (personal communication)

Sharma S R, Devendranath T and Jayaram M S 1971 Carbonatites from Nepheline syenite band near Kunavaram, Khammam district, A.P.; J. Geol. Soc. India 12 pp. 89

Siggerud T 1956 The occurrence of uranium and thorium in Norway; Int. Conf. Peaceful uses of Atomic Energy Proc. 6 178-181

Staatz M H 1974 Thorium veins in the United States; Econ. Geol. 69 494-507

Subbarao K V 1964 A note on the Radioactivity of Zircons from Vinayakapuram, Khammam district, A.P.; Indian Mineral. 5 50-52

Subbarao K V 1967 Kunavaram Series-A group of alkaline rocks from India; Curr. Sci. 36 267-268

Subbarao K V 1971 The Kunavaram senes-A group of alkaline rocks, Khammam district, Andhra Pradesh, India; J. Petrol. 12 621-641 